\title{
A Study of Changes in Liver Enzymes (ALT \& AST) with Antitubercular Treatment in Newly Diagnosed Sputum Smear Positive Patients At Rims, Ranchi
}

\author{
Dr. Umesh Prasad ${ }^{1}$,Dr. Jag Mohan Kumar, ${ }^{2}$ Dr. Kumari Madhu ${ }^{3}$ \\ Department of Medicine/ Associate Professor/ RIMS/ Ranchi University/India \\ Department of Medicine/ Senior Resident/ RIMS/Ranchi University/India \\ Department of Surgery/ADMO/Divisonal Hospital/ Adra/ India
}

\begin{abstract}
:
Introduction: Tuberculosis is caused by mycobacterium tuberculosis complex.India is the country with the highest burden of T.B.

Objective: To analyse changes in liver enzymes( ALT\& AST) with anti tubercular treatment in newly diagnosed sputum smear positive pulmonary tuberculosis patient.

Methods:Data was obtained from O.P.D and Indoor patients of Department of Medicine,, R.I.M.S, Ranchi who were suffering from pulmonary tuberculosis. 55 patients were included in this study of which 2 patients developed ATT induced hepatitis and 3 patients remained sputum smear positive even after completion of intensive phase and hence were excluded from the study.
\end{abstract}

Conclusion: There was an increase in liver enzyme level during intensive phase ofantitubercular treatment while there was a decrease in liver enzyme level in continuation phase of treatment.

Keywords: Att, Liver Enzymes, Pulmonary Tuberculosis

\section{Introduction}

Tuberculosis which is caused by mycobacterium tuberculosis complex is one of the oldest disease known to affect humans and a major cause of death world wide. ${ }^{1} \mathrm{M}$. tuberculosis is rod shaped non spore forming thin aerobic bacterium measuring $0.5 \mu \mathrm{m}$ by $3 \mu \mathrm{m}$, an acid fast bacilli. It affect, lung intestine, meninges, bones, joints,lymphnodes,spleenand other tissues of the body.India is the country with the highest burden of T.B. The WHO T.B statistics for india for 2015 give an estimated incidence figure of 2.2 million cases of T.B for india out of a global incidence of 9.6 million. In Jharkhand sputum smear positive patient diagnosed in 2015 were $20544 .{ }^{2}$ The TB prevalence is the number of people in India who are living with active TB. Prevalence is usually, but not always given as a percentage of the population. ${ }^{3}$

Total treatment period for newly diagnosed tuberculosispatients is of 6 months including intensive and continuation phases ( 2 and 4 months, respectively). The intensive phase comprised of isoniazid INH $(5 \mathrm{mg} / \mathrm{kg}$ day-1; maximum $300 \mathrm{mg} /$ day),rifampicin RIF (10 mg/kg day-1; maximum $600 \mathrm{mg} /$ day), ethambutol (EMB) $(15-20 \mathrm{mg} / \mathrm{kg}$ day -1$)$, and pyrazinamide PZA (20-25 mg/kg day-1). The continuation phase comprised daily similar doses of INH and RIF. Out of above drugs Pyrazinamide,rifampicin,isoniazid are hepatotoxic and cause increase in serum transaminase levels.

Thus present study is aimed to analyse changes in liver enzymes( ALT and AST) in different phases of treatment with antitubercular drugs.

\section{Materials And Methods}

Data was obtained from O.P.D and Indoor patients of Department of Medicine,, R.I.M.S, Ranchi who were suffering from pulmonary tuberculosis.

\section{Inclusion criteria:}

1.Newly detected sputum smear positive pulmonary tuberculosis Patients

\section{Exclusion Criteria:}

1.HIV positive patients

2.History or any indication of hepatitis or cirrhosis

3.History of regular alcohol intake

4.pregnancy or postpartum period

5. Abnormal baseline LFT

6.Patients remaining sputum smear positive after completion of 2 months of intensive phase of ATT.

7.Patients with drug induced hepatitis due to ATT during course of treatment. 
Diagnosis of ATT Induced Hepatitis: ${ }^{4,5}$

Presence of at least one of the following:

i. A rise to more than 5 the upper limit of normal (ULN) level of ALT and/or AST

ii. A rise in total serum bilirubin to more than $1.5 \mathrm{mg} / \mathrm{dl}$

iii. Any increase in AST and/or ALT above pre-treatment levels together with anorexia, nausea, vomiting, and jaundice.

\section{Baseline Evaluation:}

Baseline evaluation included clinical history, physical examination, sputum smear examination, chest radiograph, abdominal ultrasonography, complete blood cell count,ESR, LFT, and hepatitis markers.

\section{Follow-up:}

Patients were followed closely fortnightly over the first 2 months, then monthly till the end of the 6month period. In each visit, patients were assessed clinically (response to therapy, any adverse effects, and nutritional status), and biochemically including LFTs, which were repeated whenever symptoms or signs suggestive of hepatotoxicity (nausea, anorexia, malaise, vomiting, hepatomegaly, or jaundice) occurred.

\section{Results}

Total 55 patients were included in this study of which 2 patients developed ATT induced hepatitis and 3 patients remained sputum smear positive even after completion of intensive phase and hence were excluded from the study.

\begin{tabular}{|l|l|l|}
\hline \multirow{2}{*}{ DURATION } & \multicolumn{2}{|c|}{ MEAN \pm SD } \\
\cline { 2 - 3 } & \multicolumn{1}{|c|}{ ALT } & \multicolumn{1}{c|}{ AST } \\
\hline $\begin{array}{l}\text { Before initiation of } \\
\text { therapy }\end{array}$ & $19.28 \pm 4.7$ & $20.20 \pm 5.6$ \\
\hline 1 month & $60.44 \pm 34.2$ & $41.98 \pm 9.8$ \\
\hline 2 month & $64.10 \pm 31.8$ & $48.42 \pm 12.0$ \\
\hline 3 month & $51.32 \pm 14.9$ & $40.60 \pm 8.8$ \\
\hline 4 month & $47.28 \pm 11.0$ & $39.56 \pm 6.7$ \\
\hline 5 month & $40.38 \pm 7.5$ & $34.56 \pm 4.2$ \\
\hline 6 month & $37.60 \pm 7.8$ & $32.46 \pm 5.9$ \\
\hline
\end{tabular}

Table No. 1

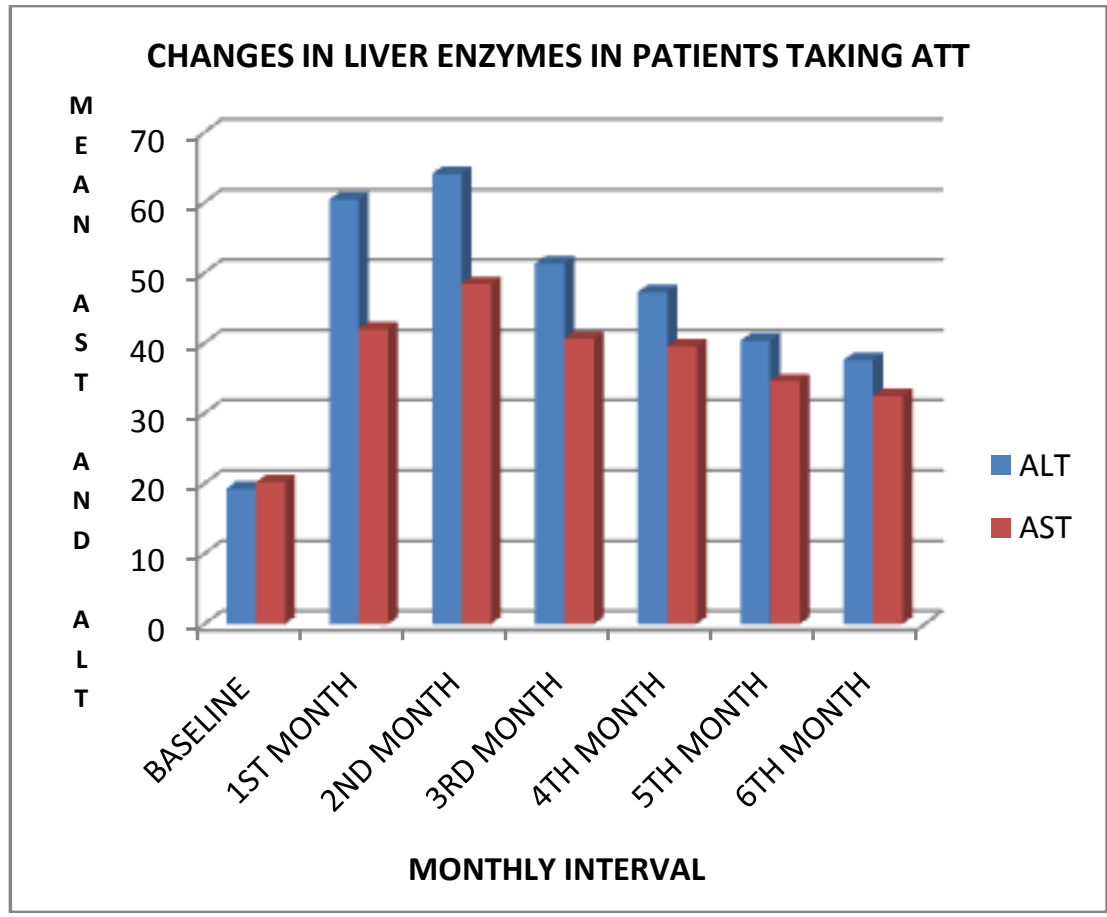

Fig- 1 


\section{Discussion And Conclusion:}

Baseline enzyme levels before therapy was within normal limits. Mean ALT level was 19.28 \pm 4.7 IU/ltr while Mean AST level was20.20 $\pm 5.6 \mathrm{IU} / \mathrm{ltr}$.After 1 month of treatment most of the patients showed increase in liver enzymes, but were mostly asymptomatic with $<3$ fold elevation of serum transaminases. Mean ALT level at 2 month was $64.10 \pm 31.8 \mathrm{IU} / \mathrm{ltr}$ while Mean AST level 48.42 $\pm 12.0 \mathrm{IU} / \mathrm{ltr}$. Thus at the end of intensive phase of treatment serum transaminase levels were in increasing trend. Mean ALT level at 3 month was $51.32 \pm 14$.9IU/ltr while Mean AST level $40.60 \pm 8.8 \mathrm{U} / \mathrm{ltr}$.There was a decrease in transaminase level in continuation phase of treatment. This shows the additive effect of multidrug therapy.

Mean ALT level at the completion of continuation phase i.e at 6 month was 37.60 $7.8 \mathrm{IU} / \mathrm{ltr}$ while Mean AST level 32.46 \pm 5 .9IU/ltr. These values were further decreased from the earlier readings taken at intensive phase and reading after commencement of continuation phase. This result is consistent with previous studies done by K.C Chang, C.C Lang \& C.M Tan. ${ }^{6}$ European Resp J 2007; De Souza AF, $1996 ;{ }^{7}$ Singh J1996 ${ }^{8}$, Altman 1993.

[1]. Harrison Principle of Internal Medicine, $19^{\text {th }} ; 1102$

[2]. $\uparrow$ “Global Tuberculosis Control 2015,WHO, Geneva, 2015 www.who.int/tb/publications/global_report/ - See more at: http://www.tbfacts.org/tb-statistics-india/\#sthash.n7evM2vw.dpuf

[3]. "Basic Statistics: About Incidence, Prevalence, Morbidity, and Mortality - Statistics Teaching Tools", Department of Health, New York State www.health.ny.gov/diseases/chronic/basicstat.htm - See more at: http://www.tbfacts.org/tb-statisticsindia/\#sthash.n7evM2vw.dpuf

[4]. Sharma SK, Balamurugan A, Saha PK, Pandey RM, MehraNK.Evaluation of clinical and immunogenetic risk factors for the developmentof hepatotoxicity during antituberculosis treatment. Am J RespirCritCareMed 2002;166:916-9.

[5]. Pande JN, Singh SPN, Khilnani GC, Khilnani S, Tandon RK. Riskfactors for hepatotoxicity from antituberculosis drugs: a casecontrolstudy. Thorax 1996;51:132-6.

[6]. Chang KC, Leung CC, Yew WW, Ho SC, Tam CM. A nested case control study on treatment related risk factor for early relapse of tuberculosis. Am J RespirCrit Care Med2004;170:1124-1130

[7]. de Souza AF, de Oliveira e Silva A, 1996. Hepatic functional changes induced by the combined use of INH,PZA\& RMP in the treatment of P.T.B ArqGastroenterol. 1996 Oct-Dec;33(4):194-200.

[8]. Singh J, Garg PK, Tandon RK. Hepatotoxicity due to antituberculosistherapy. Clinical profile and reintroduction of therapy. J ClinGastroenterol1996;22:211-4.

[9]. Altman C, Biour M, and Grange J., 1993. Hepatoxicity of antitubercular agent: Role of different drugs. Presse Med, 22: $1212-1216$ 